\title{
Increased Participation Among Cleaners as a Strategy to Improve Quality and Occupational Health
}

\section{Therese Öhrling'}

Phd in Working Life Science, Luleå University of Technology, Sweden

\begin{abstract}
Like many other industries, today the cleaning industry is affected more than ever by competition and pressure toward low prices, which leads to a nonadvantageous situation for cleaners. These days many Swedish municipalities choose to outsource cleaning service in order to save money, although the situation for the cleaners appears to be worsening. The aim of this paper is to evaluate an alternative organizational structure within a Swedish public cleaning division to investigate how good work environment for cleaners can be combined with economical savings for a municipality. Like many other cleaning organizations, both national and international, the present cleaning division has been struggling for a long time with high levels of sick leave and early retirements. After years of unsuccessful attempts to improve the situation by reducing the physical load, cleaning managers made a decision to broaden their strategy by changing the structure of their organization. In this study, both qualitative and quantitative methods have been applied to identify and understand the effects of the organizational change, both on an individual level and on an organizational level. The results show that the organizational change, which leads to increased participation and autonomy for the cleaners, in combination with a high degree of social support, had a positive effect on job satisfaction, work motivation, and pride among the cleaners. Sick leave within the division has decreased, and both the quality and efficiency of the cleaning service have increased. It can be concluded that there are other alternative organizational structures that could be applied within the public sector and prove advantageous, both for the individual cleaners and for the municipality. Further research of similar organizational structures within the private cleaning sector is recommended.
\end{abstract}

\section{KEY WORDS}

Cleaning work / Employee participation / Occupational health / Organizational commitment / Privatization / Social support / Work motivation / Work organization

\section{Introduction}

- he aim of this paper is to summarize and discuss the effects of an organizational change within a public cleaning division in a Swedish municipality. The effects have been evaluated from both an organizational and an individual perspective. The main purpose of the organizational change was to improve the health of the cleaners; additionally, it was to improve the efficiency and quality of the cleaning service in order to avoid outsourcing as well as be better prepared in case of competition. Outsourcing and increasing competition are strong global trends within the public sector today, including among Swedish municipalities (Kamp et al. 2013, TNS SIFO 2012). In Sweden, cleaning

\footnotetext{
${ }^{1}$ therese.ohrling@ltu.se
} 
service in particular has been a major target of these new arrangements as a cost-cutting strategy (TNS SIFO 2012). From an individual perspective, this trend appears to worsen the cleaner's work conditions and further increase the risk of work-related disorders, which is already very common among cleaners (EU-OSCHA 2009). There is a gap of knowledge regarding other alternatives, other than outsourcing and increased competition, which could be economically advantageous and also improve the cleaners' health. The ambition of this paper is to fill that gap. Additionally, if it is possible to show how a good work environment for cleaners can have a positive effect on the cleaning organization's profit as well, it may have a positive impact for cleaners also in the private sector as cleaners' work environments do not seem to be improved when cleaning services are made more efficient in order to save money (Søgaard et al. 2006).

The paper starts by introducing the trends within the cleaning sector in Sweden and how this affects the well-being of the cleaners. The paper then describes the methodology of the study together with a presentation of the subject of the study-the public cleaning division. The achieved results of the study are then presented and is later followed by a discussion section and conclusions.

\section{Cleaners in the modern economy}

The public sector, both global and in Sweden, is today strongly affected by privatization and outsourcing (Christensen and Lægreid 2007, Kamp et al. 2013, TNS SIFO 2012). This increases the competition and puts a great deal of emphasis on low prices, which leads to change the work situation for many occupational groups. The cleaning business is no exception and outsourcing of public cleaning services has become more common, as public organizations try to reduce their costs by focusing on their core business and outsourcing activities that are considered to play a supporting role (Aguiar and Herod 2006, EU-OSCHA 2009, Ryan 2012, Søgaard et al. 2006). In Sweden the outsourcing of public cleaning services has become a very strong trend, and many municipalities in Sweden have outsourced cleaning services today due to both financial and political reasons (Sundin and Rapp 2006, TNS SIFO 2012). Also within the private sector cleaning services are being outsourced when companies want to focus on the core business. This has led to price war and destructive competition among the growing number of cleaning companies, resulting in worsened job conditions and work intensification for cleaners, along with insecure employment situations (Abbasian and Hellgren 2012, Sundin and Rapp 2006). In a not yet published report by Almega, ${ }^{1}$ 96\% of 1,225 investigated public procurements of cleaning services between 2009 and 2011 was made on the basis of lowest cost only. Factors like quality, hygiene, and the cleaners' work environment were not considered important. This has also been recognized in international studies (see, e.g., EU-OSCHA 2009). In order to survive, the cleaning agencies are forced to cut their costs, and because a cleaning agency does not have many other costs except for the personnel, the situation becomes worse (EU-OSCHA 2009, Holley and Rainnie 2012). The cleaning sector, like the industrial sector, has also started to adopt lean, or lean-inspired, organizational strategies as an attempt to save time and money (Aguiar and Herod 2006, EU-OSCHA 2009, LO 22 2012, Puech 2007). This seems to lead to additional negative effects for cleaners, as cleaning work is not only intensified but also made more monotonous and controlled (Aguiar and Herod 2006, LO 2012, Ryan 2012). There are indications that the outsourcing of public cleaning 
services and the strong focus on lowest possible price is short-sighted and not a sustainable solution. There have been cases when Swedish municipalities have reincorporated the cleaning service within the public sector after complaints due to poor quality of service when the cleaners who are hired are forced to clean the same facilities in half the time to meet the requirements for low cost (Kommunalarbetaren 2013). It has also become more and more common that other municipal employees such as schoolteachers see their job duties expanded with cleaning duties due to the attempts to cut costs on the cleaning service. This has led to protests and complaints from the teachers who do not want to do cleaning work, and is an indication that cutbacks on cleaning services affect the quality of education since such cleaning tasks take time away from teaching (Lärarförbundet 2010). Nevertheless, the general trend does not seem to change and the outsourcing of public cleaning services is on the rise (TNS SIFO 2012).

\section{A high-risk occupation}

Cleaning work is a high-risk occupation in terms of developing work-related disorders due to both physical and psychosocial issues, such as repetitive movements, monotonous work, work in awkward positions, time pressure, loneliness, and few opportunities to influence the work and take part in decision-making processes (Abbasian and Hellgren 2012, Bell and Steele 2012, EU-OSCHA 2009, Holtermann et al. 2009, Kumar and Kumar 2008, Søgaard et al. 2006, Thalund Binderup et al. 2011, Woods and Buckle 2006). Except for high demand upon the cleaners the health problems can also be linked to a low degree of control and social support (Karasek and Theorell 1990, Theorell 2003), which are factors that have been shown to be common among cleaners (EU-OSCHA 2009, Gamperiene et al. 2006). According to Karasek and Theorell's model (Figure 1),

Figure I: The demand-control-support model of Karasek and Theorell (1990) and Theorell (2003).

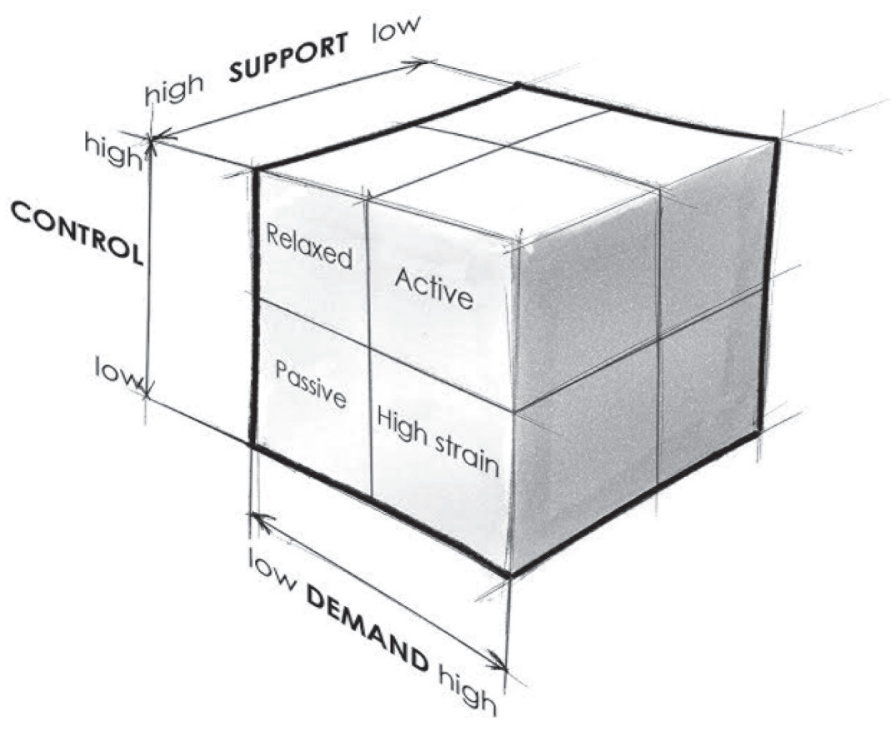


which often is used to explain the relations between work situation and health, it is possible for a person to handle higher demands if it is followed by increased control and support.

Influence at work and decision latitude among cleaners have shown to have a positive effect on musculoskeletal disorders (Holtermann et al. 2009, Søgaard et al. 2006, Unge et al. 2007). A majority of the studies about cleaning work identify the problems that are causing the poor health of the cleaners, and gives suggestions for how these problems could be reduced, for example, job rotation, increased autonomy, scheduling that allows time to rest between physically demanding tasks, although it is hard to find documented work environment improvements in practice. The results of a major questionnaire-based investigation among Swedish workers show that out of all occupational categories, cleaners not only exhibit a high degree of work-related illnesses but also appear to receive the lowest level of investment in work environment improvements $\left(\mathrm{SWEA}^{3} 2012 \mathrm{a}\right)$. Only $31 \%$ of cleaners stated that systematic work environment improvements were applied at their job site, compared to a mean value of $55 \%$ for all occupational groups. In another report from SWEA (2012b) investigating femaledominated jobs, the work environment at cleaning companies ranked highest among workplaces in terms of "unfavorable remarks," 4 out of 5 by the SWEA investigators. There appears to be a huge gap between theory (i.e., the recommendations for how cleaning work should be performed in order to increase sick absence among cleaners) and practice (i.e., current tendencies within the cleaning sector). The work conditions for cleaners are therefore worsening instead of being improved. Positive relations between good work environment and economical profit are well known (see, e.g., Abrahamsson 2000, Lagerström et al. 2009), and this has also been recognized among cleaning companies by Antonsson and Schmidt (2007). There are reasons to believe that the cleaning industry is short-sighted and only makes investments that give quick economical results. When work environment investments are made, the focus often seems to be on cleaning tools and education in good cleaning techniques instead of organizational and social factors (Pekkarinen 2009). This is probably because it is an easier strategy to apply, and the result of the investment can be measured immediately if the strategy also increases the working speed. Many of these investments are also good for the cleaners, as modern cleaning equipment and techniques can reduce their physical load (Pekkarinen 2009). However, there are indications that the time pressure on the cleaners increases when new devices or machinery is purchased (Aurell 2001, Woods and Buckle 2006). This kind of investment does not seem to offer sufficient advantages to lower sick days in the sector. It is recognized that successful work environment investments require a broad perspective that also addresses organizational and social factors (see, e.g., Abrahamsson and Johansson 2013, Eklund et al. 2006, Lagerström et al. 2009, Mathiassen 2009). Currently it does not appear that organizations in the cleaning sector are making the kinds of broad work environment investments that could serve as good examples. Many work environment problems for cleaners are social in nature, such as customers and other building occupants who act rude and disrespectful toward cleaners and are quick to criticize their work (Aurell 2001, Woods and Buckle 2006). Many cleaners also describe feeling invisible, and cleaners are often referred to as the hidden workforce since they often work during unsocial working hours or are told to not get in the way of other activities that are ranked more important (Woods and Buckle 2006). The low status of the profession can be linked to its female-dominated workforce, and the fact that 
cleaning work traditionally is categorized as women's work and therefore ranks less important than male-dominated work (see, e.g., Acker 1990). According to the SWEA questionnaire survey among Swedish employees (SWEA 2012a), cleaners are also the occupational group that rank their own work as least meaningful: only $36 \%$ of cleaners answered that their work felt meaningful, compared to a mean of $69 \%$ for all occupational groups. Cleaners were also least satisfied with their occupation-only $57 \%$ compared to a mean value of $75 \%$ for the survey population as a whole. Furthermore, $61 \%$ of cleaners described their work as monotonous, compared to the overall mean value of $20 \% ; 27 \%$ say they feel uncomfortable when going to work, compared to the overall mean of $17 \%$. These social factors are seldom further investigated in cleaning work, and recommendations for how to increase autonomy and social support for cleaners are hard to find in the literature.

\section{Methodology}

This paper is based on a 4-year longitudinal case study that started in 2009 when the public cleaning division made an organizational change. Both qualitative and quantitative methods have been applied to identify and understand the effects of the change and to answer the question of how and why it has affected the cleaners and the cleaning division. Three questionnaire surveys and two interview surveys, which were considered adequate in relation to the time frame of the study, have been carried out. The three questionnaires were addressed to all of the 86 cleaners (all female), and the response rates were $90 \%(n=80), 85 \%(n=73)$, and $85 \%(n=70)$, respectively. Employee turnover has been low, and only three of the cleaners responding to the third questionnaire (carried out in September 2011) were not there when the organizational change was made (in January 2009) and at the time the two earlier questionnaires were administered. The aim of the questionnaires was to identify the cleaning division's organizational change and to investigate the cleaners' experiences of it. The cleaners were also asked about their physical and mental health and how they rated their perceived level of demand, control, and social support at work on a 6-point scale (according to Karasek and Theorell 1990, Theorell 2003).

For the two sets of interviews 16 and 12 cleaners, respectively, participated. The first set was conducted in October 2009 and the second in October 2012. The cleaning managers and the head of the municipality division to which the cleaning division belonged were also interviewed at the beginning of the project. All of the interviews were individual and semi-structured (Fontana and Frey 1994) lasting between 30 and 60 minutes. A recorder was used during the interviews, and each interview was transcribed word-by-word for analysis. Among the cleaners who voluntarily reported themselves to the interviews the selection was made to get a wide range of ages, number of years in the industry, and different experiences of working in teams and working on their own. The aim of the first interview survey was to investigate the cleaners' experiences of the organizational change and how they perceived their work situation. In the second interview survey the aim was similar, although the aim was also to investigate why the cleaners who worked on their own appeared to not identify themselves as lonely or isolated, as cleaners who work without coworkers often are described (see, e.g., EU-OSCHA 2009, Woods and Buckle 2006). Therefore, the selection criterion to only 
interview cleaners who were working without coworkers at the time of the interview was added. The cleaners in both the interview surveys were working in a varied sample of facilities, including schools, preschools, offices, and elder care facilities. A handful of the cleaners had also been employed previously by private agencies. All of the interviewed cleaners had an open-ended employment and most of them were working full time, eight hours a day. The age of the cleaners participating in the interviews varied from 20-30 up to 65 years. The mean age of those surveyed was likely similar to the mean age for the division as a whole ( 49 years). The age of the individual participant cleaners was not asked during the interviews, as the question made some of the cleaners uncomfortable. Maybe they did consider the age too personal to tell or that they became worried about their anonymity if their answers could be linked to their age. The cleaners participating in the interviews were guaranteed anonymity and were also informed of their rights of leaving the interview if and whenever they wanted. All of the interviews were conducted by the author, a younger female researcher, and any unequal power dynamic could be attributed to differences in education and social status of the profession, and less likely to gender or age. However, the cleaners could have assessed the researcher's possibility to affect their work situation through the result of the study as high, which could have been affected the cleaners' responds. This is one of the study's weaknesses, and it is likely that the cleaners' and the cleaning managers' answers are overly optimistic if they believe that a positive result of the organizational change can work in favor of not being a basis for outsourcing and competition. This is discussed further in the discussion section of the paper.

Furthermore, financial data have been collected from the cleaning division and from the municipality. Meetings and other gatherings with the cleaning division have also been attended and observed to learn about the division's organization, as well as the social relations both between cleaners, and between cleaners and managers. Continuous communication with the cleaning managers has been maintained and internal information has been taken into account during the study. As the issues in the cleaners' work environment are complex and the employees' experiences of their work situation are likely to change over time, the broad range of methods in this study in combination with the long time frame is one of the study's strengths. Furthermore, the relations between work environment investments and economic profit are also said to be challenging to study, as numerous variables always affect the economic situation (Eklund et al. 2006). A broad perspective with different kinds of methods is more likely to increase the validity of the study, and gives a more accurate picture of the relationship between work environment and economic effects.

\section{The cleaning division}

The cleaning division's municipality is located in the north of Sweden, and is populated by 42,000 . The division is one of many subdivisions within the public organization, which all are $100 \%$ financed by tax money. The municipality controls and regulates the subdivisions as well as provides them with administrative support. Being a division in a Swedish municipality means being part of a solidarity system with a shared financial system. Any surplus in one division can be transferred to a division with a shortfall at the end of each year. Like other public cleaning divisions in Sweden, the present cleaning 
division is a nonprofitable organization and the division's clients consist exclusively of other publicly owned services (e.g., public schools, preschools, and kindergartens). As the present municipality has not yet allowed competition for cleaning services, which an increasing number of Swedish municipalities have, the clients are not allowed to purchase cleaning services from private cleaning companies. The cleaning division is also not allowed to sell its services on the private market. This segregates the public cleaning services from private market and, according to trade union magazine (e.g., Fastighetsfolket) as well as other studies (see e.g., Sundin and Rapp 2006), big differences in favor of public sector employees have been identified in terms of employee insurance, and the possibility of securing full-time work with open-ended contracts, for example. The cleaners within the different sectors are also members of different trade unions, and this put different demands upon the employers.

The present cleaning division employs 86 cleaners, all female, and the mean age is 49 years. All of the cleaners have the possibility to work full-time, eight hours a day, which the majority do. The cleaners do also have open-ended employments. The cleaners are divided into four geographic areas, and one cleaning manager leads each area. All four cleaning managers are also female. The cleaning division has, for many years, been struggling with high utilization of sick days and early retirements. The cleaning managers state that they have always provided all employees with modern cleaning tools and machinery, as well as educated them in ergonomic techniques and offered health care programs. Nevertheless, sick days continued to be high.

\section{Result}

\section{The cleaning division's organizational change}

According to the interviews the cleaning managers believed that the lack of improvements of the health situation among the cleaners, despite their earlier efforts to improve the physical work environment, was that decisions and cutbacks made by the municipality had negative effects on the cleaners' work situation, and countered the positive effects that could come of their investments. The managers have in mind that the situation probably would have been even worse without their effort, but they were still not pleased with the situation. The frustration among the cleaning managers, and the cleaners, was growing, and they felt an urge to change the situation. During the first interview survey in 2009, one of the cleaning managers said:

Neither we, the cleaners, nor the clients had any say in it, but it was just done. We noticed that when people who don't know cleaning work made those cutbacks it increased the burden on the employees. So many people got sick. It was terrible. The cleaners, who know the work and the routines, must be involved and listened to. We have always been at the top, or bottom (depending on the perspective), when it comes to sick leave statistics in the municipality; it's no fun. We employ young healthy people to help us with this job and then when they get sick, we spit them out 'on the other side' in their 50s, when they are hurt and sick. 'Thank you and goodbye.' It doesn't feel good. So, it was probably where it started. What can we do? 
The managers felt that they needed to increase their own power to influence the organization in order to achieve a better work environment for the cleaners. This was made through a contract between the cleaning division and the municipality, which increased the cleaning division's independence, although it also decreased the division's support from the municipality. In Swedish, the cleaning division became an intraprenad, literally an "intrapreneurship." The contract was the division's own initiative and was at first opposed by the municipality; however, after four years of negotiation and new political governance, the municipality finally accepted the cleaning division's wish. The duration of the contract was three years, and when the first period expired in January 2012, the municipality was pleased with the cleaning division's new organization and was willing to renew the contract for three more years if the cleaning division so wanted. A vote was carried out among cleaning managers and cleaners and the result was favorable. Until today, the cleaning division is the only one of the municipality's subdivisions that has this kind of contract. Since the contract the cleaning division is partly cut off from the solitary economical system within the municipality, which allows the division to share each other's surplus and shortfalls. The cleaning division is now allowed to keep $50 \%$ of any surplus in the end of each year; similarly, it can only get a maximum of $50 \%$ in reimbursement in case of a financial shortfall. Any kept surplus can be used to improve the quality of cleaning service, and it is up to the cleaning managers to decide how to allocate it. It cannot be used for any monetary bonuses.

Thus, the initial purpose of the organizational change was to improve the health of cleaners, but an additional aim with the new organization was growth; this aim sought to avoid being outsourced to private agencies, or to be better prepared in the event of competition. Even though they cannot know how the situation would be if the threat becomes a reality, the cleaning managers and the cleaners strongly believe that privatization or competition would have a negative impact on their work situation. The cleaners also fear ending up unemployed. One of the older cleaners said:

'You can't do the same thing forever, you have to change, otherwise the private agencies will be there and that is dangerous. You can end up unemployed or be forced to work very fast, and at least I can't do that.'

(Interviewed cleaner 2009)

Some of the cleaners who had previously been employed by private cleaning companies offered testimony about poorer work conditions and greater time pressures within the private sector. The managers and the cleaners are also affected by what is written in Swedish trade union magazines (e.g., Fastighetsfolket) and other cleaning industry magazines as well (e.g., Rent), which repeatedly give examples of how the work situation for cleaners has become tougher. The organizational change has therefore not only sought to create a good work environment for the cleaners, but also become a strategy to increase quality, efficiency, and customer satisfaction. They believe these are key factors which could steer the municipality away from outsourcing, or could make the clients still choose the cleaning division over a private company if both alternatives were available. The two citations below are from two electronic letters that the cleaning managers wrote to the employees in 2010 and 2011, respectively:

'We have to ask ourselves how well we are prepared in the case of being subject to competition. What can we do better, more effectively or at a lower cost? How can we prove 
that we are the best alternative if, or when, the time comes? Even if competition is not yet upon us, we can't sit back and think that we are safe. It happens in municipalities all around us and seems to be a general trend. Together, we have to find good strategies, and we must all pull together.'

'If the clients had the opportunity to choose, would we be their first choice? We all have a responsibility to contribute. Today it is not enough to be good enough; today we need to be the best, all the time.'

The cleaning managers and the cleaners are convinced that the increased independence that has come from the internal contract is the only way they can become the respectable and high-quality cleaning organizations they know that they have the potential to be. The managers see the contract as a necessary action to develop and provide both a good work environment for the cleaners and to use tax money in a more economical and efficient way. Even though the cleaning managers underscore that the main purpose of the organizational change is to improve the work environment for the cleaners, factors such as efficiency, quality, and customer satisfaction-which can be said to have a direct effect on the bottom line-are now also a part of the purpose.

\section{Increased participation and autonomy for the cleaners}

After the contract was signed, the cleaning managers continued the organizational change by passing on the new independence to the cleaners by increase the cleaner's participation and autonomy. For example, staff councils consisting of cleaners only, and a steering committee, consisting of both cleaners and the cleaning managers, was organized in order to improve cleaners' participation within the organization. Participation in staff councils is voluntary; a new staff council is started whenever there is a need, and they are disbanded when the assignment is done. Meetings for the councils are arranged during ordinary working hours approximately 2 hours a week. Assignments include such things as evaluating and purchasing new cleaning equipment and work wear or devising new health care strategies to improve the physical and mental health of coworkers. The cleaning manager estimates that about two councils are running at any given time, and that approximately five cleaners are participating in each council. The cleaners who are a part of the steering committee together with the cleaning managers have been elected by their coworkers to represent them, serving on the committee for three years. The steering committee meets approximately once a month and plays a leadership role in the organization. Both the three questionnaire and the interviews indicate that the cleaning managers have succeeded with the strategy to improve the cleaner's participation and possibility to influence the organization. The majority of the cleaners state that in several areas they experience greater participation and involvement in decision-making processes and the ability to affect the cleaning organization than before. Diagram 1 shows the result of questionnaire 1 , conducted six months after the organizational change.

The ability to affect customer relations and the cleaning division's economics were the factors that appear to have been improved the most according to questionnaire 1. A total of $38 \%$ of the cleaners stated that they felt a strong possibility to affect the division's economy after the organizational change, compared to $13 \%$ who felt the same 
Diagram I: Percentage of cleaners who answered " 5 " or "6" on a 6-point scale where "I" represented not at all and " 6 " represented very much, for their ability to affect on five different factors, before and after the organizational change.

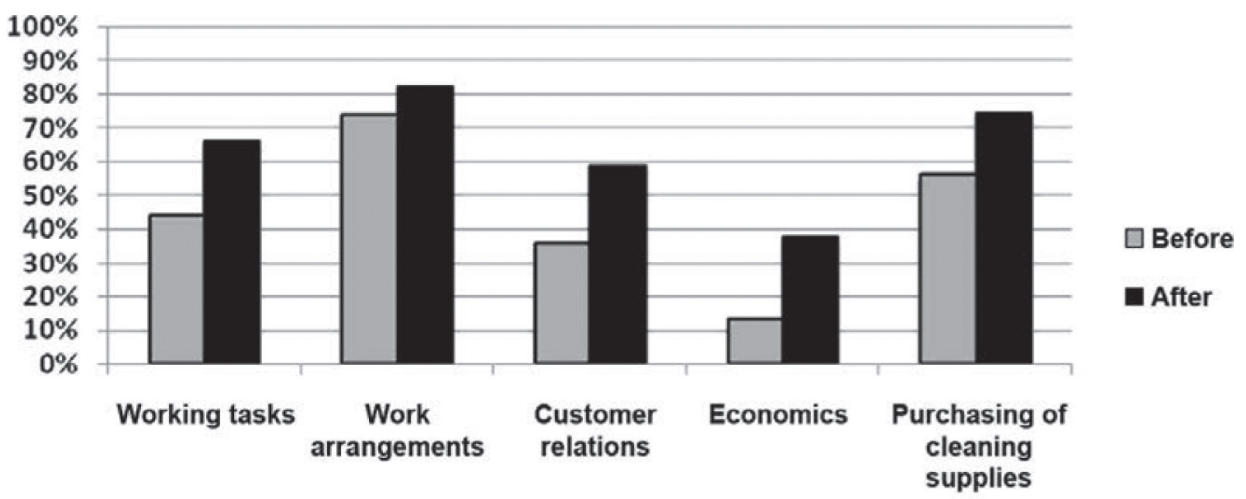

before. The interviews show the same results as the questionnaires; cleaners felt they had a greater ability to affect their own work situation, as well as customer relations and the cleaning division's economy after the organizational change. The cleaners did also express a greater financial responsibility, since they now feel more able to affect it. During the interviews most of the cleaners said that they were more aware now than before of how they used the division's assets, such as the purchasing of cleaning supplies and when they asked for assistance or a substitute cleaner. One of the interviewed cleaners said,

"Now we ask ourselves, "do we need extra assistance today or can we do it anyway." Before (the organizational change) you might call for assistance unnecessarily, you could have done it on your own if you had thought it through first.'

(Interviewed cleaner 2009)

The increased responsibility and feeling empowered to affect different parts of the cleaning division seem to have led to work motivation and job satisfaction. One of the cleaners interviewed in October 2009 said,

'People now are more positive and optimistic. We are feeling that we now are doing this for our division and us. Now we want to do a good job to make this work.'

(Interviewed cleaner 2009)

The team spirit and connection between the cleaners at different work sites have also increased. One cleaner said:

'I believe it is beneficial that we now consider ourselves to be 'in the same boat'. Otherwise I would just care about this place where I'm cleaning, I would not care about the others, at other work sites, because what they do does not affect me.'

(Interviewed cleaner 2009)

Theoretically, many of the strategies to improve participation and autonomy for the cleaners could have been applied even without the internal contract, although the 
cleaning managers state that it was the contract that gave both them and the cleaners the motivation and courage necessary to take the leap.

\section{Improved communication and faster decision-making processes}

The cleaning division's organizational change has in several ways increased communication within the division. For example, the staff councils and the steering committee serve not only the main purpose of increasing participation but have also improved communication among cleaners and between cleaners and their managers. Many of the interviewed cleaners said that they appreciated the social part of the councils and steering committee, as they otherwise are more or less isolated from each other due to the geographic distances between the work sites. The councils and steering committee therefore have become a new platform for the cleaners to meet and share their cleaning experience and knowledge that otherwise would not have been shared.

Since the organizational change, the cleaning managers have been writing a weekly electronic newsletter to all the cleaners in the division. The letter contains information from the managers and the municipality that concerns the cleaning division. The letter also includes the cleaning managers' observations on trends in the cleaning industry and how these might affect the cleaning division. The managers also encourage the cleaners to communicate with each other through the newsletter by contributing information or requests. The letter is written in an attempt to generate enthusiasm and to increase job satisfaction among the cleaners. Team spirit is often emphasized in the newsletters, and cleaners are encouraged to support and help each other. The cleaners are also welcome to bring attention to and acknowledge coworkers who they think deserve extra appreciation or encouragement for any reason. The cleaners said that they appreciated the newsletters and that it increased their insight into things that concern the division. The newsletter has become a link between all the cleaners, and it also appears to contribute to an increased feeling of connection and solidarity.

Another consequence of the contract between the cleaning division and the municipality is the shorter decision-making processes as many decisions now can be made within the cleaning division and do not need to be processed higher in the hierarchy of the municipality. For example, decisions regarding client requests have become shorter, and the cleaning managers have also given the cleaners an increased autonomy to handle those decisions and to make their own agreements with the clients. Today, the cleaners are always the first contact between the clients and the cleaning division. Communication between customer and cleaning manager never goes over the head of the cleaner. One of the cleaners said that before the internal contract it could take a very long time to fulfill clients' requests - up to a year-from when the request was made to when the matter was resolved, and the risk of misunderstandings was high due to the long process. One said:

'Before, many of the clients' requests never reached a conclusion, as they never got through to the last person in the decision-making process. And we were not allowed to do anything before we got an approval from the person in charge. Now it is so simple. We, on our own, can take the initiative and just call our manager, and she can just say "Yes, lets do that", and we do it and the client is pleased. It feels like you are more effective now."

(Interviewed cleaner 2012) 
The interviews show that the social relations between cleaners and clients have been improved since the organizational change. This is probably due to the shorter decisionmaking processes (which have increased face-to-face contact) and the increased focus on client satisfaction. A positive relation between good social relations (i.e., between cleaners and clients) and shorter decision-making processes has also been identified by Antonsson and Schmidt (2007). This relation can take on a certain level of importance for those cleaners who are working without coworkers. In the second interview survey among 12 cleaners who worked without coworkers, none of the cleaners stated that they felt alone, invisible, or in any way disrespected during work. Instead, the cleaners seemed to have developed good social relations with the clients and other building occupants at the work sites, such as teachers, school cafeteria staff, office workers, and so on. The increased positive feedback the cleaners were given by their clients led to job satisfaction and pride in their work. During the interviews many of the cleaners did reflect upon their work in terms of low social status, which they did associate with the female-dominated workforce. However, none of the cleaners said that they had personal experiences of this at the present time. Instead they stated that they were always treated with respect by others at the same work sites. The low status of cleaning work, which can be associated with many of the work environment problems that cleaners face (Abbasian and Hellgren 2012, Woods and Buckle 2006), appears to be decreased by increasing cleaners' autonomy and social contact with clients.

\section{Work intensification}

Even though many positive effects have come of the organizational change, there are reasons to believe that the work has become more intense both for the cleaners and for the cleaning manager. Work intensification can be described as increased workload without additional time in compensation (Burchell 2002). This seems to be the case among the cleaners in this study, as the cleaners now are attending more meetings and are assigned more administrative work, which has been added on top of ordinary work tasks. For some of the new assignments, such as longer meetings and activities that involve many cleaners, substitute cleaners are temporarily hired. Nevertheless, many times cleaners need to compensate for the lost time on their own, alternatively reprioritizing cleaning tasks. One cleaner said:

\section{'If you want to have influence, you have to learn and participate. I believe it has been more work for everybody.'}

(Interviewed cleaner 2009)

However, according to the interviews and the questionnaires, a majority of the cleaners do not consider this a problem. Instead they are happy for the changes that are made and express a greater job satisfaction, pride, and work motivation than before, even though many of them felt an intensification of the work. The lack of competition might also have an impact on the cleaner's experiences of time pressure, which in the interviewees and in the questionnaires was described as moderate. Only $4.5 \%$ of cleaners rated their stress level as a 5 or a 6 on a 6-point scale where 6 represented very stressed during an ordinary working hour. Many of the cleaners sign up for voluntary assignments, 
although some of the interviewed cleaners and a handful of the responding cleaners in the questionnaires did hint that sometimes there were too many meetings, education sessions, or administrative information to take in, so they sometimes had a hard time finishing their ordinary work (even though they did not take part in any staff councils or the steering committee). Regardless, most of these cleaners still felt positive toward the new organizational system, as they felt an increased ability to influence the division if they so wanted. It is important that cleaning managers are aware of different individual needs among the cleaners and not push the participation strategy too far.

\section{Improved health among the cleaners}

According to the statistics of sick days provided by the municipality, the number of sick days has decreased dramatically since 2005 , both for the municipality as a whole and for the cleaning division (Diagram 2).

This quick drop between 2007 and 2009 is most likely a result of the financial crisis and the new "tougher" guidelines for financial compensation during sick leave that were applied in Sweden 2008, which have been shown to be two important factors in sick leave statistics throughout the country (SWEA 2011, The Swedish Social Insurance Agency 2008). Nevertheless, cleaners' absenteeism has decreased more than the mean for all the municipal employees and is now on the same relatively low level as the municipality as a whole, around $5 \%$, which can be considered as a very low rate of absenteeism for cleaners (Antonsson and Schmidt 2007). The cleaning managers explain the quick drop in sick days between 2006 and 2009 as due to the many early retirements and termination of employees who were on long-term sick leave in times when the municipality was forced to save money and could not offer those employees alternative working tasks. According to the cleaning managers, the low number of sick days today is thanks to the organizational change in combination with the investments in the physical work environment. Today fewer cleaners take sick leave due to workrelated disorders, even though the mean age in the division is still high, at 49 years. Instead, most sick days are not related to work. Some of the cleaners have lately also been diagnosed with cancer, which affects the statistics without being related to the work environment.

Diagram 2: Sick leave statistics of the employees in the municipality and the cleaning division

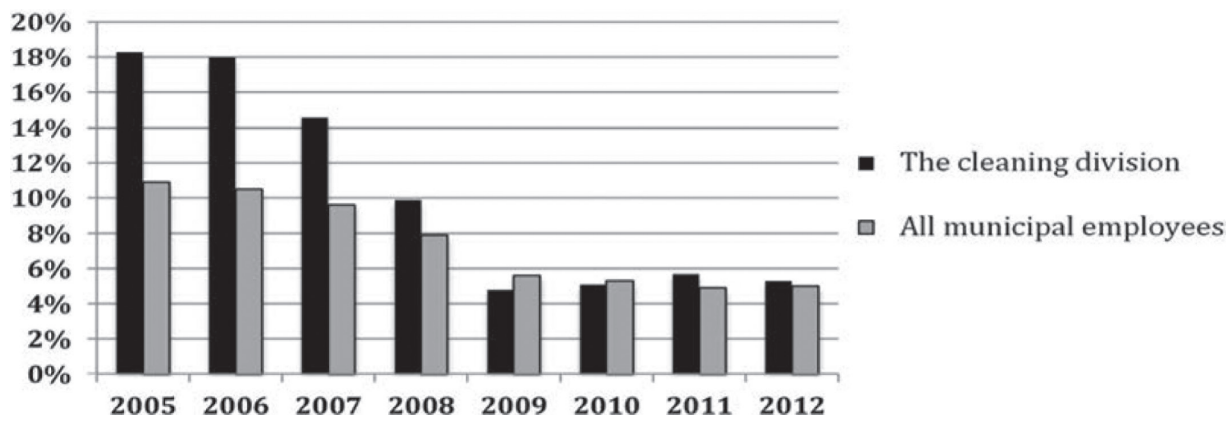




\section{Economical effects}

Probably due to the fact that the cleaning division is a part of the Swedish public sector, financed by tax money and a nonprofit organization, the division's economical annual result has not changed since the reorganization. The cleaning division has, for many years, even before the organizational change, ended each year with a budgetary surplus. The cleaning division has since the internal contract was signed, redistributed their own economic resources, which has affected the costs of the division. The biggest financial change for the cleaning division is a reduced cost of administrative services to the municipality, as the cleaning division now has chosen to do most of this work on its own. This cost has therefore been lowered by 2,000,000 SEK (306,000 USD/232,000 EUR) each year, which is a reduction of over $70 \%$. Additional to this, the cleaning managers estimate that they are saving 700,000 SEK (105,000 USD/80,000 EUR) each year due to lower costs for employee rehabilitation following injury, reduced costs, work-related sick days, fewer hours of substitute cleaners, less waste of cleaning supplies, lower employee turnover, and fewer errors in cleaning services that need to be redone thanks to the organizational change. The managers also believe that many costs have been cut thanks to cleaners' increased awareness and responsibility for the division's financial situation. The approximately 2,700,000 SEK that the cleaning division is saving each year due to the cut costs is being reinvested within the division. One of the bigger investments was to hire the fourth cleaning manager, which the three original managers felt a need for in order to maintain the same level of social contact with the cleaners due to the increased administrative tasks associated with the internal contract. The cleaning managers also invest extra money in education for the cleaners, in team-building activities for the cleaners, and in extra staffing during intense periods, e.g., during fall and spring when more dirt gets inside and increases the workload. The money is also used to improve the communication and social contacts between the cleaners in order to both improve the psychosocial work environment for the cleaners and to increase the dissemination of knowledge between the employees.

According to the cleaning managers, the division's provided finances are now used in a more sustainable way, which improves the work environment for the cleaners and increases the quality of the cleaning service. Unfortunately, the municipality's financial system has made effects on the financial details hard to follow, as the system is inconsistent and many cost centers have changed names or been split up or merged over this time span. Also many of the costs, for example, the cost for vacancy cleaners, have according to the cleaning managers both been decreasing (due to the lower sick absence among the cleaners and the more cost conscious personnel) and increasing (in order to lower the physical load for the cleaners during intense periods), which has made the economical analyses hard to confirm as only the total cost has been provided.

\section{Discussion}

The cleaning division's organizational change appears to have led to higher productivity and quality of the cleaning service, as well as an improved work environment for the cleaners. Both cleaners and managers feel they have a higher degree of responsibility, work motivation, and ability (and willingness) to influence the organization. These 
factors can be related to the concept of organizational commitment (see, e.g., Berglund 2007), which describes the employee's degree of loyalty toward the organization and willingness to contribute to achieve the organization's goal. This is a very desirable situation for employers, but the literature recognizes it as hard to achieve, and many attempts have failed (Berglund 2007, Mankelow 2002). Good communication and mutual trust between employers and employees, as well as the employee's ability to influence the organization are said to be critical for achieving organizational commitment (Gallie et al. 1998). Attempts to increase those factors are common, although in reality many of these attempts simply improve one-way communication, which in practice does not change the situation for the employees and may instead lead to increased frustration and mistrust (Mankelow 2002). The three questionnaire surveys and the two sets of interviews in this study show that the cleaners now are experiencing a greater possibility to influence and take part in decision-making processes. These are factors that have been associated with physical health among cleaners (Holtermann et al. 2009, Søgaard et al. 2006, Unge et al. 2007). Communication and trust between cleaners and the cleaning managers have been somewhat improved according to the questionnaires, although both the questionnaires and the interviews show that the social relation between cleaners and managers was already good before the organizational change. All of the cleaners who were interviewed testified to the healthy functioning of two-way communication between cleaners and managers. The cleaners also feel that their managers always ask for and listen to their opinions. The fact that the cleaning division has managed to increase factors that other studies recognize as hard to achieve-such as work motivation, organizational commitment, and functional two-way communication-is probably due to the mutual trust between cleaners and cleaning managers. Trust seems to have built up over many years and is a result of the manager's involvement and concern for the cleaners and their work situation. The cleaners also report that the managers always consider themselves and the cleaners as equal and look upon every individual employee as equally important for the organization. It is possible that this equal cleaner/manager and cleaner/cleaner relationship might have been a key factor to the successful implementation of the organizational change. Gender is often a factor that creates segregation and hierarchies within the organization (see, e.g., Abrahamsson 2002, Acker 1990), which also has been observed within cleaning organizations (see, e.g., Puech 2007). There are reasons to believe that the gender homogeneous organization, as both the cleaners and the managers are all women, has an impact of the equality within the organization. However, this paper does not recommend gender homogeneous organizations as a strategy to achieve equality.

So far the cleaning division is pleased with the results they have accomplished, as they have both lowered the sick absence and have not yet become a subject for competition. Although in a way the cleaning division has created its own work intensification in an attempt to escape it, they believe that is what is going to happen in the case of privatization or competition. However, the fact that the initiative to make those changes comes from within the division might give a feeling of control, together with a great amount of social support and mutual trust between the cleaners and the managers, could be the reason for why the cleaners do not frame the work intensification as negative but rather as a source of motivation. This can be illustrated by the demand-control-support model (Figure 1) (Karasek and Theorell 1990, Theorell 2003) which shows that increased demands do not need to have negative effects if it is followed by a high degree of control and social support. According to the results of the interviews and the questionnaires, 
the cleaner are experiencing increased control and social support from their coworkers, their managers, and their clients compared to before the organizational change. Also, the lack of competition probably has a positive impact on the cleaner's experiences of time pressure and stress, which they rate as moderate. This might indicate that there was an open possibility of intensifying work for many of the cleaners to a certain degree without producing negative effects. In the cleaning division it appears that all three factors in the demand, control, and support model have increased, and the cleaners therefore now are closer to the "active square" which may provide the feeling of work motivation and self-fulfillment. It is possible that previously the cleaners were closer to the "passivesquare," which is associated with boredom and low stimulus (Figure 1). It is important to remember that the model is subjective and how a person perceives a situation is individual. What one person considers boring another might consider safe and secure, or sufficiently challenging (Thylefors 2009). Also, the time factor must be considered, and it is possible that the cleaners' experiences of the work situation today might be different from in the future. Maybe it is the charm of the novelty that today leads to the positive reactions, while the negative effects will be more noticeable as time goes by. However, four years have now passed and the cleaners are still expressing positive attitudes, as they did in the beginning of this study; this indicates that the cleaning division's strategy could be a sustainable situation.

It is possible that the cleaners' and the cleaning managers' statements in this study are overly optimistic, for many possible reasons. One is that they might believe that the risk of being outsourced decreases if the head of the municipality hears about good results of their organizational change. A second reason is that they might want to emphasize themselves and their occupations, as they have witnessed too many media and research reports that produce a negative picture of the profession. The cleaners could also be motivated by a willingness to please their managers, or the researcher, by saying the things they think we want them to say. However, the meetings and team-building activities, which have been attended during the study, were characterized by an atmosphere that was joyful, spontaneous, and relaxed between the cleaners and the managers. And if it were true that the cleaners and managers wanted to emphasize their division and its organizational change as more successful than it really is, this could be interpreted as a very strong organizational commitment, which is good both for the cleaners and for the division. So far the cleaning division is one of the divisions in the municipality that reports a financial surplus each year, and as the cleaning division also contributes with $50 \%$ of their budget surplus back to the department the municipality is not yet planning to outsource the cleaning service. The municipality appears to consider the cleaning division an asset. The division is also putting the municipality on the map in a positive way, as they have gotten attention from the media and been awarded with national prizes for their work environment. The Swedish Work Environment Authority is also using the division as a good example in a campaign for how to achieve a healthy work site, which benefits both the employees and the employers (Företagshällsokollen 2012).

Many of the cleaners in the interviews state that their work has not changed since the organizational change; they feel that they are still doing the same job, in the same way, and in the same facilities as before the organizational change. Nevertheless, they do express a greater job satisfaction and work motivation than before, which could come from an increased feeling of control, responsibility, and ability to influence their own situations. This is interesting, as it shows that cleaners' work situation, and how cleaners 
feel about their work, can be improved in ways other than by improving physical work environment factors. However, for many cleaners in this study their ordinary cleaning work has been expanded to include administrative work, which has increased job variety and could be good from a physical work environment perspective (Hägg et al. 2009). Also, it appears that the physical work environment for the cleaners in this study is overall good and cleaners who have experiences from prior cleaning jobs reported that the division offered better physical conditions than are found in the cleaning sector in general. This topic has not been verified through further investigations, but it is likely that the overall physical work environment for the municipal cleaners is, and has been, favorable, as the cleaning tasks are varied; modern techniques, machinery, and tools have been purchased; and the cleaners have been educated in ergonomic cleaning techniques. Nevertheless, this study shows that these kinds of investments are not enough to lower absenteeism for the cleaners. It was not until the organizational change, when also organizational and social factors were included, that the positive results started to show and fewer cleaners got sick from work-related disorders. This result is in line with Antonsson and Schmidt's (2007) findings, which finds a positive relation between low levels of sick absence among cleaners and a high degree of investments in both the physical and the psychosocial work environment. Several other studies dealing with health and work environment investment have found that, a broad perspective that includes many different aspects of work is essential in order to improve health among employees (Abrahamsson and Johansson 2013, Eklund et al. 2006, Neumann et al. 2010).

\section{Concluding remarks}

It can be concluded that the cleaning division through increased participation, autonomy, and ability to influence the work for the cleaners, in combination with a continuous ambition to improve the physical work environment, has created a suitable and good work environment for the employees. The social relations and trust between the cleaners and the managers was in both the interviews and in the questionnaires rated very high, and seem to have been key factors for the positive effects of the organizational change. The increased autonomy and shorter decision-making processes have also improved the communication and the social relations between cleaners and other employees at the work sites. Other studies describe these factors as poor and having a negative effect on the psychosocial work environment for cleaners (EU-OSCHA 2009, Gamperiene et al. 2006, Woods and Buckle 2006). The cleaners in this study are now experiencing work motivation, job satisfaction, and pride, and a significantly lower number of cleaners are getting sick from work-related disorders compared to before the organizational change. This study goes in line with many other studies which give evidence of the importance of a broad perspective, which includes both physical and psychosocial factors, in order to improve the health of the employees (see, e.g., Abrahamsson and Johansson 2013). However, the result also shows that the cleaning division's organizational change has led to work intensification for the cleaners. A majority of the cleaners experience this intensification as motivating and stimulating, but others are concerned of work enlargement and too many meetings which takes time away from their ordinary work. Although, without the organizational change and the work intensification, it is likely that the municipality by now would have outsourced the cleaning 
division, or exposed it for competition, it could have led to an even higher work intensification for the cleaners.

This study shows a positive relation between work environment investments and competitive advantages. The results can therefore be compared to the results of many other studies, which find similar relations between good work environment and higher productivity (see, e.g., Abrahamsson 2000, Eklund 1995, Lagerström et al. 2009, Mathiassen 2009). Through redistribution of the financial resources in combination with more cost-conscious personnel with increased autonomy, the quality and efficiency of the cleaning service have increased. Also, the shorter decision-making processes and the improved communications between cleaners and customers have improved the customer satisfaction. The result indicates that there are other alternatives other than outsourcing and competition that can work in favor for both the individual cleaners and the municipality. The cleaning managers believe that they are now better prepared if the market for cleaning services at municipal institutions is opened to competition, and they believe that they have a chance to compete with private companies due to their increased efficiency and quality. Even though the cleaning division in this study is a public cleaning organization that operates without competition and without interest in economical profit, their strategy should be possible to adopt with positive results also within other kinds of cleaning organizations, in either the public or the private sectors. Further research of similar organizational structures within the private cleaning sector is recommended.

\section{References}

Abbasian, S., Hellgren, C. (2012) Working conditions for female and immigrant cleaners in Stockholm county - an intersectional approach. Nordic Journal of Working Life Studies 2(3), 161-181.

Abrahamsson, L. (2000) Production economics analysis of investment initiated to improve working environment. Applied Ergonomics 31, 1-7.

Abrahamsson, L. (2002) Restoring the order: gender segregation as an obstacle to organisational development. Applied Ergonomics 33, 549-557.

Abrahamsson, L., Johansson, J. (2013) One hundred years of inertia. An Exposé of the concept of the psychosocial work environment in Swedish policy and research. Nordic Journal of Working Life Studies 3(1), pp 5-29.

Acker, J. (1990). Hierarchies, jobs, bodies: a theory of gendered organizations. Gender and Society, 4(2), 139-158.

Aguiar, L., Herod, A. (2006) The Dirty Work of Neoliberalism: Cleaners in the Global Economy. Blackwell Publishing. Malden, US.

Antonsson, A.-B., Schmidt, L. (2007) Städföretag som ligger före och tjänar på det. Kan vi lära av goda exempel och vad kan vi lära? (Cleaning agencies that is ahead and keep and profit from it. Can we learn from good examples and what can we learn?) Report B1720. Svenska Miljöinstitutet, Stockholm.

Aurell, M. (2001) Arbete och Identitet. Om hur städare blir städare. (Work and identity: On how cleaners become cleaners) Doctoral thesis. Linköpings Universitet, Sweden.

Bell, A. F., Steele, J. R. (2012) Risk of musculoskeletal injury among cleaners during vacuuming. Ergonomics 55(2), 237-247.

Berglund, T. (2007) Flexible work situations and employee's thoughts of leaving the organization. In: Furåker, B., Håkansson, K., Karlsson, J. Ch. (eds.) Flexibility and Stability in Working Life Houndmills, Basingstoke: Palgrave Macmillan, New York, pp. 162-164. 
Burchell, B. (2002) The prevalence and redistribution of job insecurity and work intensification. In: Ladipo, D., Wilkinson, F., Burchell, B. J. (eds.) Job Insecurity and Work Intensification. Routledge, London, pp. 61-76.

Christensen, T., Lægreid, P. (2007) Introduction-theoretical approach and research questions. In: Christensen, T., Lægreid, P. (eds.) Transcending New Public Management-The Transformation of Public Sector Reforms. Ashgate, Aldershot. pp. 1-16.

Eklund, J., Hansson, B., Karlqvist, L., Lindbeck, L., Neumann, W. P. (2006) Arbetsmiljöarbete och effekter - en kunskapsöversikt. (Work environment investments and effects - a review). Arbete och Hälsa, 2006:17 SWEA.

EU-OSCHA (2009) Brun, E., González, E. R. (eds.) The Occupational Safety and Health of Cleaning Workers. European risk observatory. Literature review.

Fontana, A., Frey, J., (1994) Interviewing: the art of science. In: Denzin and Lincoln. Handbook of Qualitative Research, 361-376. Sage Publications, Thousand Oaks, CA.

Gallie, D., White, M., Cheng, Y., Tomlinson, M. (1998) Restructuring Employment Relationship, Clarendon Press, Oxford, New York.

Gamperiene, M., Nygård, J. F., Inger Sandanger, I., Wærsted, M., Dag Bruusgaard, D. (2006) The impact of psychosocial and organizational working conditions on the mental health of female cleaning personnel in Norway. Journal of Occupational Medicine and Toxicology $1,24$.

Holley, S., Rainnie, A. (2012) Who cleans up? The declining earnings position of cleaners in Australia. The Economic and Labor Relations Review 23(1), 143-160.

Holtermann, A., Blangsted, A. K., Hansen, K., Søgaard, K. (2009) What characterizes cleaners sustaining good musculoskeletal health after years with physically heavy work? International Archive of Occupational Environmental Health 82, 1015-1022.

Hägg, G. M., Ericson, M., Odenrick, P. (2009) Physical load. In: Bohgard, M., Karlsson, S., Lovén, E., Mikaelsson L. Å., Mårtensson, L., Osvalder, A. L., Rose, L., Ulfvengren, P. (eds.) Work and Technology on Human Terms. 129-189, PREVENT, Stockholm.

Kamp, A., Klemsdal, L., Gonäs, L. (2013) Working in the public sector - introduction to the thematic issue. Nordic Journal of Working Life Studies 3(2), 1-8.

Karasek, R., Theorell, T. (1990). Healthy Work. Basic Books, New York.

Kumar, R., Kumar, S. (2008) Musculoskeletal risk factors in cleaning occupation - a literature review. International Journal of Industrial Ergonomics 38, 158-170.

Lagerström, G., Rose, L., Lovén, E. (2009) Work environment and economics. Chapter 12, In: Bohgard, M., Karlsson, S., Lovén, E., Mikaelsson, L.-Å., Mårtensson L., Osvalder, A.-L., Rose, L., Ulfvengren, P. (eds.) Work and Technology on Human Terms. PREVENT (Work environment in association with the Confederation of Swedish Enterprise, LO \& PTK), Stockholm, Sweden.

LO (2012) Gellerstedt, S. Fler arbetare måste få utvecklande jobb - inte digital Taylorism (More workers must get challenging job - not digital Taylorism).

Mankelow, R. (2002) The organisational costs of job insecurity and work intensification. In: Ladipo, D., Wilkinson, F., Burchell, B. J. (eds.) Job Insecurity and Work Intensification. Routledge, London, pp. 137-153.

Mathiassen, S. E. (2009) Arbetsmiljö, arbetshälsa, framgång, lönsambet...(Work environment, health, success, profitability...). In: God arbetsmiljö - en framgångsfaktor? Arbetspolitiska Kunskapsrådet SOU 2009:47. Stockholm.

Neumann, W. P., Eklund, J., Hansson, B., Lindbeck, L. (2010) Effects assessment in work environment interventions: a methodological reflection. Ergonomics 53(1), 130-137.

Pekkarinen, A. (2009) Development in professional cleaning work brings challenges to ergonomics. The Ergonomics Open Journal 2, 40-46.

Puech, I. (2007) Cleaning time, protest time: employment and working conditions for hotel maids. Sociologie du travail 49, 50-65. 
Ryan, S. (2012) When is a team a team? "Teamworking” and the reorganization of work in commercial cleaning. Employee Relations 34(3), 255-270.

SWEA (2011) Nedåtgående trend av anmälda arbetsskador - Tillfälligt avbrott? (Downward trend of occupational injuries - temporary break?) Stockholm.

SWEA (2012a) Arbetsmiljön 2011. (The work environment 2011). Report 2012:4 Stockholm, Sweden.

SWEA (2012b) Delrapport - Tillsynsaktivitet inom regeringsuppdraget om kvinnors arbetsmiljö. (Progress report - Supervisory activities within the government commission on women's work environment) Report 2012:11.

Søgaard, K., Blangstedt, A. K., Herod, A., Finsen, L. (2006) Work design and the labouring body: examining the impact of work organization on Danish cleaners' health. Antipode. Blackwell Publishing, Oxford, UK, and Maiden, MA.

Thalund Binderup, A., Holtermann, A., Søgaard, K., Madeleine, P. (2011) Pressure pain sensitivity maps, self-reported musculoskeletal disorders and sickness absence among cleaners. International Archive of Occupational and Environmental Health 84, 647-654.

The Swedish Social Insurance Agency (2008) Sjukersättning och särskilda regler - steglös avräkning m.m. (Health insurance and legislation) - Vägledning 2008:3 Version 2.

Theorell, T. (2003) Är ökat inflytande på arbetsplatsen bra för folkhälsan? Kunskapssammanställning. (Is increased participation good for public health? A review). Statens folkhälsoinstitut.

Thylefors, I. (2009) Psychosocial work environment. In: Bohgard, M., Karlsson, S., Lovén, E., Mikaelsson, L.-Å., Mårtensson, L., Osvalder, A.-L., Rose, L., Ulfvengren P. (eds.) Work and Technology on Human Terms (pp. 19-69) PREVENT, Stockholm.

TNS SIFO (2012) for ISS. Outsoursingbarometern-1012. En årlig undersökning bland Sveriges kommuner och landsting. (Outsourcing attitude/tendensies-2012. An annual survey of Sweden's public sector).

Unge, J., Ohlsson, K., Nordander, C., Hansson, G.-Å., Skerfving, S., Balogh, I. (2007) Differences in physical workload, psychosocial factors and musculoskeletal disorders between two groups of female hospital cleaners with two diverse organizational models. International Archive of Occupational and Environmental Health 81, 209-220.

Woods, V., Buckle P. (2006) Musculoskeletal ill health amongst cleaners and recommendations for work organizational change. Industrial Ergonomics 36, 61-72.

\section{Web sites}

Företagshällsokollen (2013) http://foretagshalsokollen.se/nyckel-4/Accessed: 2014-04-01 Kommunalarbetaren (2013) http://www.ka.se/index.cfm?c=104727 Accessed: 2013-09-03 Lärarförbundet (2010) http://www.lararforbundet.se/web/ws.nsf/documents/003FF68D? OpenDocument. Accessed: 2013-09-03

\section{End notes}

1 The employer and trade organization for the Swedish service sector.

2 The central organization for 14 affiliates that organizes workers within both the private and the public sectors in Sweden.

3 The Swedish Work Environment Authority. 